Check for updates

Cite this: RSC Adv., 2018, 8, 7832

\title{
Antiacetylcholinesterase triterpenes from the fruits of Cimicifuga yunnanensis $\uparrow$
}

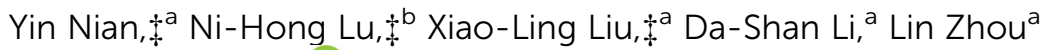 \\ and Ming-Hua Qiu (iD) *a
}

Two new cycloartane triterpenes, cimyunnin E (1), containing a unique oxaspiro[4.4]nonanedione moiety based on rings $D$ and $E$, together with cimicifine $B(2)$, a 25,26,27-trinortriterpene featuring a pyridine ring $E$, were purified from the fruits of Cimicifuga yunnanensis. Their structures were elucidated by spectroscopic methods and ECD (electronic circular dichroism calculations). Compounds 1 and 2 showed significant acetylcholinesterase (AChE) inhibition with $I C_{50}$ values of 1.58 and $3.87 \mu \mathrm{M}$, respectively. In addition, they noticeably enhanced the neurite outgrowth of nerve growth factor (NGF) mediated PC12 cells at a concentration of $10 \mu \mathrm{M}$.

Received 11th January 2018

Accepted 10th February 2018

DOI: 10.1039/c8ra00291f

rsc.li/rsc-advances

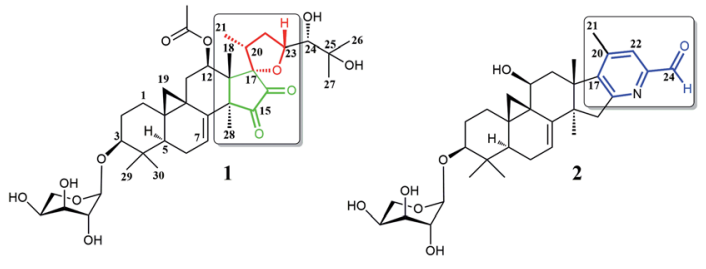

Fig. 1 Structures of compounds 1 and 2.

studies on the fruits of C. yunnanensis. Consequently, another two novel triterpenes, cimyunnin E (1) and cimicifine B (2), were isolated and identified (Fig. 1). Compound 1 represents the first example of CTs with an unprecedented oxaspiro[4.4]nonanedione unite formed in ring $\mathrm{D}$ and $\mathrm{E}$. While, compounds 2 is a trinortriterpene containing a pyridine ring E. Significantly, biological evaluations revealed that compounds 1 and 2 were strong AChE inhibitors with $\mathrm{IC}_{50}$ values of 1.58 and $3.87 \mu \mathrm{M}$, respectively (the $\mathrm{IC}_{50}$ value of positive control tacrine is $0.17 \mu \mathrm{M}$, see Table S1 and Fig. S22†). Moreover, the neuronal differentiation of NGF-mediated PC12 cells were also enhanced by compounds 1 and 2 at the concentration of $10 \mu \mathrm{M}$ (Table S2 and Fig. S23†). Described herein are the isolation, structure elucidation, and biological activities of these compounds.

\section{Results and discussion}

${ }^{a}$ State Key Laboratory of Phytochemistry and Plant Resources in West China, Kunming Institute of Botany, Chinese Academy of Sciences, Kunming 650201, People's Republic of China. E-mail: mhchiu@mail.kib.ac.cn

${ }^{b}$ Department of Respiratory Medicine, The Third People's Hospital of Kunming, Kunming 650041, People's Republic of China

$\dagger$ Electronic supplementary information (ESI) available: 1D and 2D NMR spectra, HRESIMS, UV, IR, and OR spectra of new compounds $\mathbf{1}$ and $\mathbf{2}$, and ECD data of $\mathbf{1}$. See DOI: 10.1039/c8ra00291f

\$ Yin Nian, Ni-Hong Lu, and Xiao-Ling Liu contributed equally.
Cimyunnin E (1), white powder, had the molecular formula $\mathrm{C}_{37} \mathrm{H}_{54} \mathrm{O}_{12}$ as determined by the HRESIMS at $\mathrm{m} / \mathrm{z} 713.3515[\mathrm{M}+$ $\mathrm{Na}]^{+}$(calcd 713.3513), corresponding to 11 double-bond equivalents. The IR spectrum showed absorptions attributable to $\mathrm{OH}$ (3425 $\left.\mathrm{cm}^{-1}\right)$, carbonyl $\left(1745 \mathrm{~cm}^{-1}\right)$ and olefinic $\left(1603 \mathrm{~cm}^{-1}\right)$ groups, respectively. In the ${ }^{1} \mathrm{H}$ NMR spectrum (Table 1), downfield shifted cyclopropane methylene signals at $\delta_{\mathrm{H}} 0.69$ 
Table $1{ }^{1} \mathrm{H}$ and ${ }^{13} \mathrm{C}$ NMR data of compounds 1 and $2(\delta$ in ppm, $J$ in $\mathrm{Hz}$ )

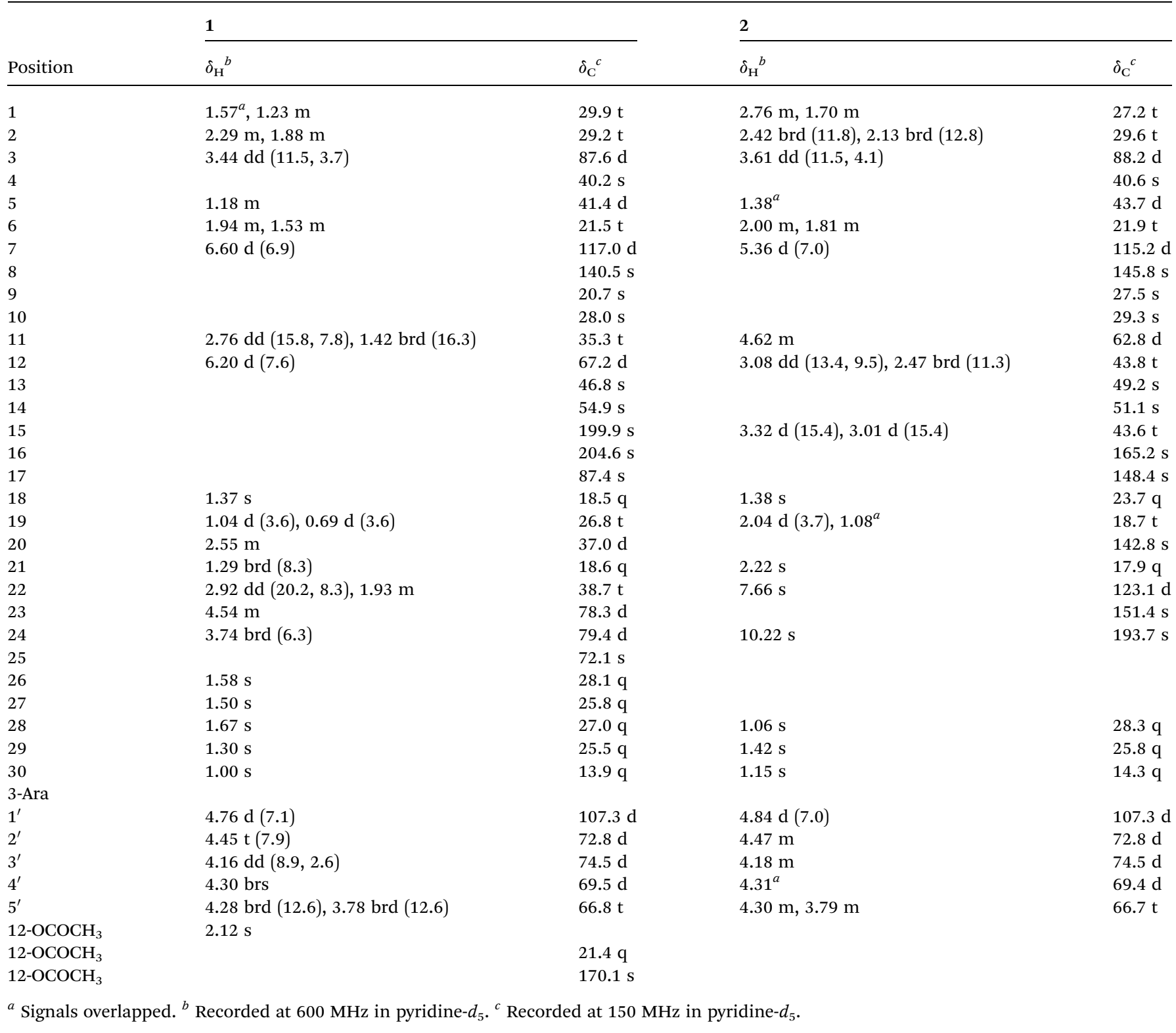

and 1.04 (each $1 \mathrm{H}, \mathrm{d}, J=3.6 \mathrm{~Hz}$ ) and an anomeric proton resonance at $\delta_{\mathrm{H}} 4.76(\mathrm{~d}, J=7.1 \mathrm{~Hz})$ were observed. The ${ }^{13} \mathrm{C}$ (Table 1) and HMQC spectra revealed the existence of two olefinic carbons at $\delta_{\mathrm{C}} 117.0(\mathrm{C}-7, \mathrm{~d})$ and $140.5(\mathrm{C}-8, \mathrm{~s})$, an ester carbonyl group at $\delta_{\mathrm{C}} 170.1(\mathrm{~s})$, two carbonyl carbons at $\delta_{\mathrm{C}} 199.9$ $(\mathrm{C}-15, \mathrm{~s})$ and $204.6(\mathrm{C}-16, \mathrm{~s})$, and six oxygenated carbon atoms at $\delta_{\mathrm{C}} 87.6(\mathrm{C}-3, \mathrm{~d}), 67.2(\mathrm{C}-12, \mathrm{~d}), 87.4(\mathrm{C}-17, \mathrm{~s}), 78.3$ (C-23, d), 79.4 $(\mathrm{C}-24, \mathrm{~d})$, and $72.1(\mathrm{C}-25, \mathrm{~s})$, respectively. These data suggested that 1 was a highly oxygenated CTs glycoside with a six-ring skeleton.

The detailed 1D and 2D NMR analyses established the planar structure of 1. The ${ }^{1} \mathrm{H}-{ }^{1} \mathrm{H}$ COSY (Fig. 2) spectrum disclosed that 1 has partial structures $-\mathrm{CH}_{2} \mathrm{CH}_{2} \mathrm{CH}-$ (due to $\mathrm{C}-1$ to $\mathrm{C}-3$ ), $-\mathrm{CHCH}_{2} \mathrm{CH}$ - (for C-5 to C-7), and $-\mathrm{CH}_{2} \mathrm{CH}-$ (for $\mathrm{C}-11$ to $\mathrm{C}-12$ ), that were compatible for rings $\mathrm{A}, \mathrm{B}$, and $\mathrm{C}$ of the CTs with a pair of double bond at C-7 and C-8. ${ }^{27,29}$ The existence of the downfield shifted cyclopropane methylene $\left(\delta_{\mathrm{H}} 0.69\right.$ and 1.04) further supported this deduction. The acetoxy group was located to C-12 on the basis of the HMBC correlation of $\mathrm{H}-12\left(\delta_{\mathrm{H}}\right.$ $6.20)$ and the ester carbonyl group $\left(\delta_{\mathrm{C}} 170.1\right)$. Similarly, the sugar unit was attached to C-3 by the HMBC coupling between
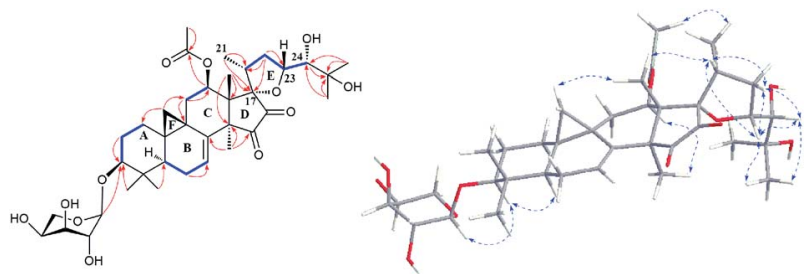

Fig. 2 Major $\mathrm{HMBC}(\longrightarrow),{ }^{1} \mathrm{H}-{ }^{1} \mathrm{H}$ COSY ( $\longrightarrow$ ), and ROESY $(4---\rightarrow)$ correlations of compound 1 . 
the anomeric proton $\left(\delta_{\mathrm{H}} 4.76\right)$ and $\mathrm{C}-3\left(\delta_{\mathrm{C}} 87.6\right)$. In addition, the sugar obtained after acid hydrolysis was identified as L-arabinose by comparing its TLC and specific rotation with a standard. Thus, ring A, B, C, F, and the sugar unit of 1 was constructed as shown (Fig. 2).

The spin system $-\mathrm{CH}_{3} \mathrm{CHCH}_{2} \mathrm{CHCH}-$ due to Me-21, C-20, C22, C-23 and C-24 was also deduced from ${ }^{1} \mathrm{H}-{ }^{1} \mathrm{H}$ COSY correlations (Fig. 2). In addition, $\mathrm{HMBC}$ correlations from $\mathrm{CH}_{3}-21\left(\delta_{\mathrm{H}}\right.$ 1.29) and $\mathrm{H}-22(2.92,1 \mathrm{H})$ to the oxygenated quaternary carbon at $\delta_{\mathrm{C}} 87.4$ (C-17) indicated the linkage of C-20 and C-17 (Fig. 2). Similarly, the connection of C-24 to the isopropanol group (C25, C-26, and C-27) was elucidated by the HMBC couplings of $\mathrm{H}-24\left(\delta_{\mathrm{H}} 3.74\right) \mathrm{CH}_{3}-26\left(\delta_{\mathrm{H}}\right.$ 1.58) and $\mathrm{CH}_{3}-27\left(\delta_{\mathrm{H}} 1.50\right)$ to the hydroxyl substituted quaternary carbon at $\delta_{\mathrm{C}} 72.1$ (C-25). By now, there were still one oxygen atom and two carbonyl carbons $\left(\mathrm{C}-15, \delta_{\mathrm{C}} 199.9 ; \mathrm{C}-16, \delta_{\mathrm{C}} 204.6\right)$ need to be assigned and four degree of unsaturation unaccounted for, requiring another two rings in the final structure. In the HMBC spectrum, correlations of $\mathrm{CH}_{3}-28\left(\delta_{\mathrm{H}} 1.67\right)$ to $\mathrm{C}-14\left(\delta_{\mathrm{C}} 54.9\right)$ and $\mathrm{C}-15\left(\delta_{\mathrm{C}} 199.9\right)$ were observed, indicating the connection between C-14 and C-15. Similarly, the connection of $\mathrm{C}-13$ and $\mathrm{C}-17$ was deduced from HMBC correlations of $\mathrm{CH}_{3}-18\left(\delta_{\mathrm{H}} 1.37\right)$ to $\mathrm{C}-13\left(\delta_{\mathrm{C}} 46.8\right)$, and C$17\left(\delta_{\mathrm{C}} 87.4\right)$, respectively. Thus, to fulfill the unsaturation requirement, the molecular weight, and the chemical shift of $\mathrm{C}$ 15 and C-16, C-17 was connected to C-16 and C-23 was linked to $\mathrm{C}-17$ by an oxygen atom (based on HMBC correlations, C-17 and C-23 could be connected by the carbonyl carbon C-16. Thus, ring $\mathrm{D}$ would be a five-membered lactone ring. In that case, the chemical shift for C-15 should around $\left.\delta_{\mathrm{C}} 170.0\right)$. Therefore, an unique 15,16-cyclopentanedione-17-spiro-17,23-oxolane moiety was established in 1. Finally, the planar structure of $\mathbf{1}$ was constructed as shown (Fig. 2).

In the ROESY spectrum (Fig. 2), correlations of $\mathrm{H}-5$ (biogenetically $\alpha$-oriented) $/ \mathrm{H}-3, \mathrm{H}-3 / \mathrm{H}-1^{\prime}$, and Me-28 (biogenetically $\alpha$ oriented)/H-12 indicated the $\alpha$-orientation of $\mathrm{H}^{-1} \mathbf{1}^{\prime}, \mathrm{H}-3$, and $\mathrm{H}$ 12. Our efforts to make fine crystals from 1 failed which precluded the possibility to determine the absolute configuration directly by X-ray crystallography. However, the diagnostic ROESY couplings of Me-18 (biogenetically $\beta$-oriented) to $\mathrm{H}-20$, $\mathrm{H}-20$ to $\mathrm{H}-23$, and acetoxy methyl to Me-21 (biogenetically $\alpha$ oriented) were observed, which help to determine $\beta$-orientation of $\mathrm{H}-20$ and $\mathrm{H}-23$ and the conformation of ring $\mathrm{E}$ as shown (Fig. 2). Therefore, the relative configuration of C-17, C-20, and

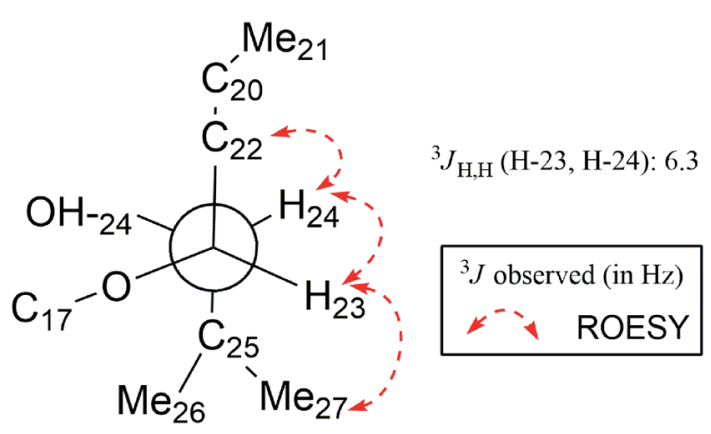

Fig. 3 The Newman projection of C-23/C-24 coupling system of 1 .
C-23 of 1 was assigned as $S^{*}, R^{*}$, and $R^{*}$, respectively. For the $17 R^{*}, 20 S^{*}$, and $23 S^{*}$ stereoisomer of 1 , those correlations would not be observed (except $\mathrm{H}-20$ to $\mathrm{H}-23$, Fig. S21†), which further confirmed this deduction. On the basis of ROESY correlations of $\mathrm{H}-23 / \mathrm{H}-24, \mathrm{H}-24 / \mathrm{H}-22$, and $\mathrm{H}-23 / \mathrm{Me}-27$ and the ${ }^{3} J_{\mathrm{H}, \mathrm{H}}$ value of $\mathrm{H}-23$ and $\mathrm{H}-24(6.3 \mathrm{~Hz})$, the Newman projection of C-23/C-24 coupling system was established as shown (Fig. 3), which help to establish the $S^{*}$ configuration of C-24. Finally, the ECD calculation was applied to determine the absolute configuration of 1. As shown in Fig. 4, spectrum calculated for the $17 S$, $20 R, 23 R$, and $24 S$ one was nearly identical with the experimental data of $\mathbf{1}$ over the whole range of wavelengths under investigation, whereas the stereoisomer exhibited very different ECD behaviour between 250-300 $\mathrm{nm}$. Therefore, the absolute configurations of C-17, C-20, C-23, and C-24 of 1 were determined as $S, R, R$, and $S$, respectively.

The molecular composition of cimicifine B (2), $\mathrm{C}_{32} \mathrm{H}_{43} \mathrm{NO}_{7}$, was deduced from HRESIMS ([M $+\mathrm{Na}]^{+}, m / z$ 576.2931), indicating 12 degrees of unsaturation. In the ${ }^{1} \mathrm{H}$ NMR spectrum (Table 1 ) of 2 , signals due to an extremely downfield shifted cyclopropane methylene at $\delta_{\mathrm{H}} 1.08$ (overlapped) and $2.04(\mathrm{~d}, J=$ $3.7 \mathrm{~Hz})$, an anomeric proton at $\delta_{\mathrm{H}} 4.84(\mathrm{~d}, J=7.0 \mathrm{~Hz})$, two olefinic hydrogen atoms at $\delta_{\mathrm{H}} 5.37(\mathrm{~d}, J=7.0 \mathrm{~Hz})$ and $7.66(\mathrm{~s})$, five tertiary methyl groups at $\delta_{\mathrm{H}} 1.06-1.42$, and an active hydrogen signal at $\delta_{\mathrm{H}} 10.22$, were observed. The ${ }^{13} \mathrm{C}$ NMR and DEPT (Table 1) spectra displayed signals for a carbonyl group $\left(\delta_{\mathrm{C}} 193.7, \mathrm{C}-24\right)$, a hydroxylmethine $\left(\delta_{\mathrm{C}} 62.8, \mathrm{C}-11\right)$, two trisubstituted olefinic carbons $\left(\delta_{\mathrm{C}} 115.2, \mathrm{C}-7 ; \delta_{\mathrm{C}} 123.1, \mathrm{C}-22\right)$, and five tetrasubstituted olefinic groups $\left(\delta_{\mathrm{C}} 145.8, \mathrm{C}-8 ; \delta_{\mathrm{C}} 165.2, \mathrm{C}-16 ; \delta_{\mathrm{C}}\right.$ $\left.148.4, \mathrm{C}-17 ; \delta_{\mathrm{C}} 142.8, \mathrm{C}-20 ; \delta_{\mathrm{C}} 151.4, \mathrm{C}-23\right)$. Therefore, aforementioned data suggested that 2 was a trinortriterpene

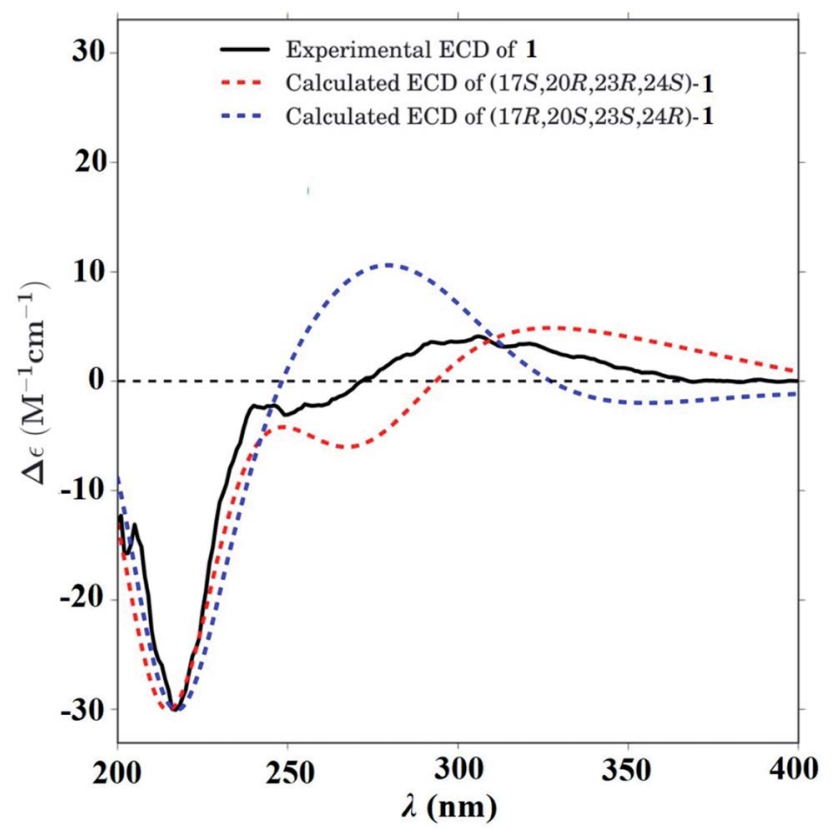

Fig. 4 Calculated ECD spectra for -(17S,20R,23R,24S)-1 (red dashed line) and $-(17 R, 20 S, 23 S, 24 R)-1$ (blue dashed line). Experimental CD spectrum of 1 (black solid line). 
glycoside and a six-ring structure, which included an unsaturated azacycle, was required to fulfill the unsaturation requirement.

Extensive analyses of 2D NMR spectra revealed the conformation of ring A, B, C, D, and F of 2 as shown (Fig. 5), which was similar to those of known compounds..$^{5-30}$ In the ${ }^{1} \mathrm{H}^{1}{ }^{1} \mathrm{H}$ COSY spectrum (Fig. 5), the correlations of $\mathrm{H}-5\left(\delta_{\mathrm{H}} 1.38\right)$ to $\mathrm{H}-6\left(\delta_{\mathrm{H}}\right.$ 1.81 and 2.00 , each $1 \mathrm{H})$ and $\mathrm{H}-6$ to the olefinic proton $\left(\delta_{\mathrm{H}} 5.37\right.$, $\mathrm{H}-7)$ indicated a pair of double bond at C-7 and C-8. The ${ }^{1} \mathrm{H}-{ }^{1} \mathrm{H}$ COSY association of the proton $\left(\delta_{\mathrm{H}} 4.62\right)$ of hydroxymethine $\left(\delta_{\mathrm{C}}\right.$ $62.8, \mathrm{C}-11)$ to $\mathrm{H}-12\left(\delta_{\mathrm{H}} 2.47\right.$ and 3.08 , each $\left.1 \mathrm{H}\right)$, together with the extremely downfield shifted proton signals of C-19 determined the location of a hydroxyl group at C-11. In the HMBC spectrum (Fig. 5), the couplings of $\mathrm{H}-15\left(\delta_{\mathrm{H}} 3.01\right.$ and 3.32 , each $\left.1 \mathrm{H}\right)$ to C$16\left(\delta_{\mathrm{C}} 165.2\right)$ and C-17 $\left(\delta_{\mathrm{C}} 148.4\right)$, and Me-18 $\left(\delta_{\mathrm{H}} 1.38\right)$ to C-17 $\left(\delta_{\mathrm{C}}\right.$ 148.4) indicated the double bond between $\mathrm{C}-16$ and $\mathrm{C}-17$. Further analysis of HMBC spectrum revealed the correlations of Me-21 $\left(\delta_{\mathrm{H}} 2.22\right)$ to C-20 $\left(\delta_{\mathrm{C}} 142.8\right)$ and C-17 $\left(\delta_{\mathrm{C}} 148.4\right)$, and $\mathrm{H}^{-}$ $22\left(\delta_{\mathrm{H}} 7.66\right)$ to C-20 $\left(\delta_{\mathrm{C}} 142.8\right)$ and $\mathrm{C}-23\left(\delta_{\mathrm{C}} 151.4\right)$, indicating the linkage of $\mathrm{C}-17 / \mathrm{C}-20 / \mathrm{C}-22 / \mathrm{C}-23$. In addition, the connection between C-23 and C-24 was elucidated by the HMBC correlation of $\mathrm{H}-22\left(\delta_{\mathrm{H}} 7.66\right)$ to the carbonyl carbon $\left(\delta_{\mathrm{C}} 193.7, \mathrm{C}-24\right)$. Thus, to fulfill the double-bond equivalents, a pyridine ring $\mathrm{E}$ should be fused to ring D through C-16 and C-17. Similarly, to fulfill the molecular weight of 2 an aldehyde group was assigned to C-24, which was further supported by the HMBC correlation of an active hydrogen $\left(\delta_{\mathrm{H}} 10.22\right)$ and C-23 $\left(\delta_{\mathrm{C}} 151.4\right)$. Finally, by the same way as that of $\mathbf{1}$, the sugar was identified as L-arabinose and located at C-3. The orientations of $\mathrm{H}-3$ and $\mathrm{H}-11$ were ascribed by the ROESY correlations (Fig. 5) between H-5 (biogenetically $\alpha$-oriented) and $\mathrm{H}-3$, and $\mathrm{H}-11$. Thus, the structure of 2 was determined as shown.

Hypothetically, prevention of acetylcholine (Ach) hydrolysis could increase the efficiency of cholinergic transmissions, which has been reported to be associated with the onset of Alzheimer's disease (AD) ${ }^{36}$ Thus, enhancement of ACh levels by potent AChE inhibitors in the brain has been considered to be an effective approach for treating $\mathrm{AD}^{37-39}$ Although prominent biological activities of CTs from Cimicifuga spp. have been reported, to date, however, anti-AChE knowledge of those chemical constituents is mainly not yet involved. Thus, the AChE

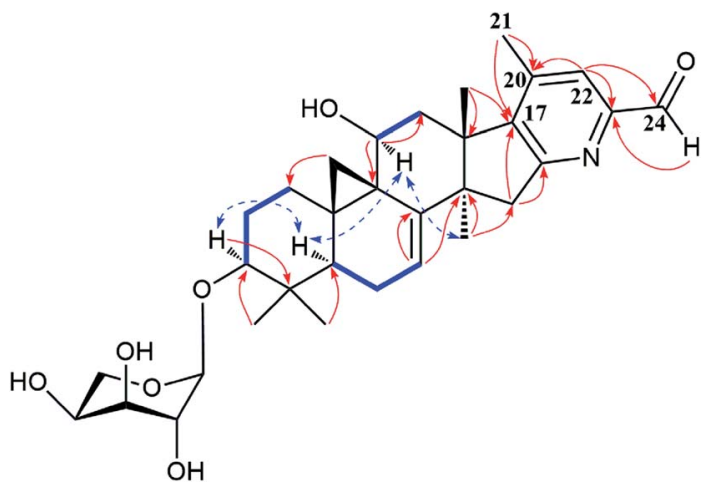

Fig. 5 Major $\mathrm{HMBC}(\longrightarrow),{ }^{1} \mathrm{H}-{ }^{1} \mathrm{H}$ COSY ( $\longrightarrow$ ), and ROESY $(4--->)$ correlations of compound 2 . inhibitory activities of compounds $\mathbf{1}$ and $\mathbf{2}$ were evaluated using the Ellman method. ${ }^{40}$ Unexpectedly, compound 1 exhibited significant inhibition on $\mathrm{AChE}$ with an $\mathrm{IC}_{50}$ value of $1.58 \mu \mathrm{M}$ (Table S1 and Fig. S22†). Similarly, compound 2 showed noticeable inhibitory effect on $\mathrm{AChE}$, having an $\mathrm{IC}_{50}$ value of $3.87 \mu \mathrm{M}$. Tacrine was used as the positive control and had an $\mathrm{IC}_{50}$ value of $0.17 \mu \mathrm{M}$.

$\mathrm{AD}$ is a type of neurodegenerative diseases. Any agent with neurotrophic activity may benefit AD. Therefore, the effects of 1 and 2 to stimulate NGF-mediated neurite outgrowth on PC12 cells were further evaluated. As a result, $\mathbf{1}$ and $\mathbf{2}$ obviously increased the neuronal differentiation at a concentration of 10 $\mu \mathrm{M}$. The differentiation rates are $15.34 \%$ and $11.72 \%$ for 1 and 2 , respectively, compared with $4.17 \%$ of the negative control and $19.18 \%$ of the positive control (Table S2 and Fig. S23†).

\section{Conclusions}

In our continual investigation on the fruits of C. yunnanensis, another two unusual CTs were obtained. Cimyunnin E (1) is the first CTs possessing an oxaspiro[4.4]nonanedione moiety in ring $\mathrm{D}$ and $\mathrm{E}$. While, cimicifine $\mathrm{B}$ (2) is a trinortriterpene contains a fused pyridine ring E. Significantly, these two compounds showed potent anti-AChE effects and neurotrophic activities. Therefore, the bioactivities of cimyunnin $\mathrm{E}$ and cimicifine B deserve further study. In summary, once again, novel active constituents were isolated from fruits of C. yunnanensis, the more sophisticated parts of this genus, such as pollen and vegetative organ are worth studying in future.

\section{Experimental section}

\section{General experimental procedures}

A JASCO P-1020 digital polarimeter was applied to record optical rotations, using $\mathrm{MeOH}$ as solvent. 1D and 2D NMR spectra were performed on Bruker DRX-500 and Avance III-600 MHz spectrometers (Bruker, Zürich, Switzerland) with solvent signal as internal reference. ESIMS and HRESIMS were run on an Agilent G6230 TOF MS (Agilent Technologies, Palo Alto, USA). Infrared spectra were tested on a Shimadzu IR-450 instrument with $\mathrm{KBr}$ pellets. Column chromatography (CC) was run on Silica gel (200-300 mesh, Qingdao Marine Chemical, Inc.), and Lichroprep RP-18 (40-63 $\mu \mathrm{m}$, Merck). Semipreparative HPLC was carried out on an Agilent 1100 liquid chromatography system using an YMC-Pack $10 \mathrm{~mm} \times 250 \mathrm{~mm}$ column (Pro C18 RS). Precoated TLC plates (200-250 $\mu \mathrm{m}$ thickness, silica gel $60 \mathrm{~F}_{254}$, Qingdao Marine Chemical, Inc.) were used for thin-layer chromatography. The spots in TLC were visualized by heating after spraying with $10 \%$ aq. $\mathrm{H}_{2} \mathrm{SO}_{4}$.

\section{Plant material}

The fruits of Cimicifuga yunnanensis $(1.5 \mathrm{~kg}$ ) were collected from Bomi County, Tibet, China, in September 2013. Prof. Wang Zongyu, Kunming Institute of Botany, Chinese Academy of Sciences, identified the species. A voucher specimen (KUN no. 201309007) has been deposited at the State Key Laboratory of 
Phytochemistry and Plant Resources in West China, Kunming Institute of Botany, Chinese Academy of Sciences, PR China.

\section{Extraction and isolation}

$\mathrm{MeOH}$ (6 L, 3 times, 7 days each) was used to extract the dried and milled fruits of Cimicifuga yunnanensis $(1.5 \mathrm{~kg})$ at room temperature. $\mathrm{MeOH}$ was evaporated under vacuum at $50{ }^{\circ} \mathrm{C}$ to afford the extract (156.3 g). The extract gave fractions A $(28.2 \mathrm{~g})$, B (31.3 g), C (29.5 g), D (27.3 g) and E (12.7 g) by silica gel CC (3.0 $\mathrm{kg}, 10 \times 150 \mathrm{~cm}$ ) eluted with $\mathrm{CHCl}_{3}-\mathrm{MeOH}[100: 0(6 \mathrm{~L}), 50: 1$ (10 L), 10 : 1 (10 L), 5 : 1 (7 L), 0 : 100 (4 L)]. Subsequently, five sub-fractions (C.1-C.5) were obtained through RP-18 CC $(1000 \mathrm{~g}, 12 \times 60 \mathrm{~cm})$, gradiently eluted with $\mathrm{MeOH}-\mathrm{H}_{2} \mathrm{O}$ from $0: 100$ to $100: 0$. Fractions (C.3.1-C.3.4) were obtained by further RP-18 CC (eluted with $\mathrm{MeOH}-\mathrm{H}_{2} \mathrm{O}$, gradient from $40: 60$ to $85: 15)$ on fraction C.3. Compound 1 (3.5 mg) was purified from fraction C.3.2 (1.4 g) by silica gel CC (40 g, $3 \times 40$ $\mathrm{cm}$ ) eluted with $\mathrm{CHCl}_{3}-\mathrm{Me}_{2} \mathrm{CO}$ (gradient from $10: 1$ to $5: 1$ ), and then repeated semipreparative HPLC (eluted with $\mathrm{CH}_{3} \mathrm{CN}$ $\mathrm{H}_{2} \mathrm{O}$, gradient from $50: 50$ to $65: 35$ ). Fraction C.2 (3.9 g) yielded compound $2(2.6 \mathrm{mg})$ by silica gel CC $(40 \mathrm{~g}, 3 \times 60 \mathrm{~cm})$ eluting with $\mathrm{CHCl}_{3}-\mathrm{Me}_{2} \mathrm{CO}$ from $20: 1$ gradient to $10: 1$ and repeated semipreparative HPLC (eluted with $\mathrm{CH}_{3} \mathrm{CN}-\mathrm{H}_{2} \mathrm{O}$, gradient from $55: 45$ to $70: 30)$.

$(3 \beta, 12 \beta, 17 S, 20 R, 23 R, 24 S)-17,23-E p o x y-15,16$-dione-12-acetoxy-3,25-dihydroxy-7-en-9,19-cycloart-3-O- $\alpha$-larabinopyranoside (1). White powder; $[\alpha]_{\mathrm{D}}^{24}=-304.0(c 0.10, \mathrm{MeOH})$; IR (KBr): $\nu_{\max } 3425,2927,2853,1745,1603,1460,1382,1242,1085$, $989 \mathrm{~cm}^{-1}$; UV (MeOH) $\lambda_{\max }(\log \varepsilon): 205$ (0.28), 250 (0.04); see Table 1 for ${ }^{1} \mathrm{H}$ NMR (600 MHz, $\left.\mathrm{C}_{5} \mathrm{D}_{5} \mathrm{~N}\right)$ and ${ }^{13} \mathrm{C}$ NMR $(150 \mathrm{MHz}$, $\left.\mathrm{C}_{5} \mathrm{D}_{5} \mathrm{~N}\right)$ data; positive ESIMS $[\mathrm{M}+\mathrm{Na}]^{+} \mathrm{m} / z$ 713; positive HRESIMS $[\mathrm{M}+\mathrm{Na}]^{+} m / z 713.3515$ (calcd for $\mathrm{C}_{37} \mathrm{H}_{54} \mathrm{NaO}_{12}, 713.3513$ ).

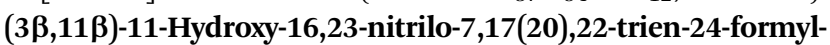
25,26,27-trinor-9,19-cycloart-3-O- $\alpha$-larabinopyranoside (2). White powder; $[\alpha]_{\mathrm{D}}^{19}=-4.8(c 0.13, \mathrm{MeOH}) ; \mathrm{IR}(\mathrm{KBr}): \nu_{\max } 3426$, 2927, 2854, 1707, 1630, 1599, 1451, 1383, 1259, 1070, $589 \mathrm{~cm}^{-1}$; $\mathrm{UV}(\mathrm{MeOH}) \lambda_{\max }(\log \varepsilon): 203$ (0.55), 273 (0.13); see Table 1 for ${ }^{1} \mathrm{H}$ NMR (600 MHz, $\left.\mathrm{C}_{5} \mathrm{D}_{5} \mathrm{~N}\right)$ and ${ }^{13} \mathrm{C}$ NMR $\left(150 \mathrm{MHz}, \mathrm{C}_{5} \mathrm{D}_{5} \mathrm{~N}\right)$ data; positive ESIMS $[\mathrm{M}+\mathrm{Na}]^{+} \mathrm{m} / z$ 576; positive HRESIMS $[\mathrm{M}+\mathrm{Na}]^{+}$ $m / z 576.2931$ (calcd for $\mathrm{C}_{32} \mathrm{H}_{43} \mathrm{NNaO}_{7}, 576.2937$ ).

\section{Hydrolysis and identification of the sugar units in compounds 1 and 2}

The $\mathrm{MeOH}$ solution (3 mL) of each compound $(1.5 \mathrm{mg}$ ) was refluxed with $0.5 \mathrm{~N} \mathrm{HCl}(2 \mathrm{~mL})$ for $2 \mathrm{~h}$. $\mathrm{CHCl}_{3}(3 \times 6 \mathrm{~mL})$ was used to extract the reaction mixture after diluting with $\mathrm{H}_{2} \mathrm{O}$. A monosaccharide was given by neutralizing each aqueous layer with $\mathrm{Ag}_{2} \mathrm{CO}_{3}$ and filtering the precipitate. The monosaccharide from compounds 1 and 2 had an $R_{\mathrm{f}}$ (EtOAc- $\mathrm{CHCl}_{3}-\mathrm{MeOH}-\mathrm{H}_{2} \mathrm{O}$, $3: 2: 2: 1)$ and specific rotation of $[\alpha]_{\mathrm{D}}^{20}+85.4(c 0.08, \mathrm{MeOH})$ corresponding to those of L-arabinose (Sigma-Aldrich).

\section{Acetylcholinesterase inhibitory activity}

Acetylcholinesterase (AChE) inhibitory activities of compounds 1 and 2 were assayed by the spectrophotometric method developed by Ellman et $a l^{40}$ with slightly modification. $S$ -
Acetylthiocholine iodide, 5,5'-dithio-bis-(2-nitrobenzoic) acid (DTNB, Ellman's reagent), and acetylcholinesterase derived from human erythrocytes were purchased from Sigma Chemical. Compounds 1 and $\mathbf{2}$ were dissolved in DMSO. The reaction

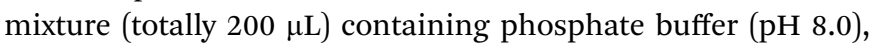
test compound (50 $\mu \mathrm{M}$ for preliminary screening; 100, 50, 30, $10,3,1$, and $0.2 \mu \mathrm{M}$ for $\mathrm{IC}_{50}$ value assay), and acetylcholinesterase $\left(0.02 \mathrm{U} \mathrm{mL}^{-1}\right)$ was incubated for $20 \mathrm{~min}\left(30^{\circ} \mathrm{C}\right)$. Then, the reaction was initiated by the addition of $40 \mu \mathrm{L}$ of solution containing DTNB (0.625 mM) and acetylthiocholine iodide $(0.625 \mathrm{mM})$ for AChE inhibitory activity assay. The hydrolysis of acetylthiocholine was monitored at $405 \mathrm{~nm}$ every 30 seconds for one hour. Tacrine was used as positive control with final concentration of $0.333 \mu \mathrm{M}$ for preliminary screening and 2, 1 , $0.5,0.2,0.04,0.008$, and $0.0016 \mu \mathrm{M}$ for $\mathrm{IC}_{50}$ value assay. All the reactions were performed in triplicate. The percentage inhibition was calculated as follows: $\%$ inhibition $=(\mathrm{NC}-S) / \mathrm{NC} \times$ 100 (NC (negative control) is the activity of the enzyme without test compound and with $2 \%$ DMSO and $S$ is the activity of enzyme with test compound and the final concentration of DMSO is $0.1 \%$ ). Inhibition curves were obtained for each compound by plotting the percent inhibition versus the logarithm of inhibitor concentration in the assay solution. The linear regression parameters were determined for each curve and the $\mathrm{IC}_{50}$ values extrapolated. The same procedure was applied for the positive control tacrine.

\section{Neurite outgrowth-promoting activity}

The neurotrophic activities of the tested compounds were examined according to an assay using PC12 cells as reported. ${ }^{\mathbf{4 1}}$ Briefly, PC12 cells (purchased from Kunming institute of zoology) were maintained in F12 medium (Ham's F12K, Gibco's reagent) supplemented with $12.5 \%$ horse serum (HS, Hyclone's reagent), and $2.5 \%$ fetal bovine serum (FBS, Hyclone's reagent), and incubated at $5 \% \mathrm{CO}_{2}$ and $37^{\circ} \mathrm{C}$. Tested compounds were dissolved in DMSO. For the neurite outgrowth-promoting activity bioassay, PC12 cells were seeded at a density of $5 \times 10^{4}$ cells per $\mathrm{mL}$ in 48 -well plate coated with poly-L-lysine (sigma's reagent). After $24 \mathrm{~h}$, the medium was changed to that containing $10 \mu \mathrm{M}$ of each test compounds plus $5 \mathrm{ng} \mathrm{mL} \mathrm{m}^{-1} \mathrm{NGF}$ (sigma's reagent), or different concentrations of NGF ( $50 \mathrm{ng} \mathrm{mL}{ }^{-1}$ for the positive control, $5 \mathrm{ng} \mathrm{mL} \mathrm{m}^{-1}$ for the negative control). The final concentration of DMSO was $0.05 \%$, and the same concentration of DMSO was added into the negative control. After $72 \mathrm{~h}$ incubation, the neurite outgrowth was assessed under a phase contrast microscope. Neurite processes with a length equal to or greater than the diameter of the neuron cell body were scored as neurite bearing cells. The ratio of the neurite-bearing cells to total cells (with at least 100 cells examined per view area; 5 viewing area per well) was determined and expressed as a percentage.

\section{ECD calculation}

The theoretical calculations were carried out using Gaussian 09. ${ }^{42}$ Structures were first optimized at PM6 using semiempirical theory method and then optimized at HF/6-31G(d) 
theory level. Room-temperature equilibrium populations were calculated according to Boltzmann distribution law (eqn. (1)). The conformers with Boltzmann-population of over $1 \%$ were chosen and further optimized at B3LYP/6-311G(d,p) in methanol using the IEFPCM model (Table S3†). Vibrational frequency analysis confirmed the stable structures.

$$
\frac{N_{\mathrm{i}}}{N}=\frac{g_{\mathrm{i}} \mathrm{e}^{-\frac{E_{\mathrm{i}}}{k_{\mathrm{B}} T}}}{\sum g_{\mathrm{i}} \mathrm{e}^{-\frac{E_{\mathrm{i}}}{k_{\mathrm{B}} T}}}
$$

where $N_{\mathrm{i}}$ is the number of conformer i with energy $E_{\mathrm{i}}$ and degeneracy $g_{\mathrm{i}}$ at temperature $T$, and $k_{\mathrm{B}}$ is Boltzmann constant. Under the same condition, the ECD calculation was conducted using time-dependent density functional theory (TD-DFT). Rotatory strengths for a total of 30 excited states were calculated. The ECD spectrum was simulated in SpecDis ${ }^{43}$ by overlapping Gaussian functions for each transition according to (eqn. (2)):

$$
\Delta \varepsilon(E)=\frac{1}{2.297 \times 10^{-39}} \times \frac{1}{\sqrt{2 \pi \sigma}} \sum_{\mathrm{i}}^{A} \Delta E_{\mathrm{i}} R_{\mathrm{i}} \mathrm{e}^{-\left(\frac{E-E_{\mathrm{i}}}{2 \sigma}\right)^{2}}
$$

where $\sigma$ represents the width of the band at $1 / e$ height, and $\Delta E_{\mathrm{i}}$ and $R_{\mathrm{i}}$ are the excitation energies and rotatory strengths for transition i, respectively. Parameters of $\sigma$ and UV-shift for enantiomers were $0.5 \mathrm{eV}$ and $1 \mathrm{~nm}$, respectively.

\section{Conflicts of interest}

There are no conflicts of interest to declare.

\section{Acknowledgements}

This project was supported by the National Natural Science Foundation of China (81302670 and U1132604) and the Foundation of State Key Laboratory of Phytochemistry and Plant Resources in West China, Kunming Institute of Botany, CAS (P2015-KF03).

\section{Notes and references}

1 E. Liske and P. Wustenberg, Menopause, 1998, 5, 250-255.

2 D. J. McKenna, K. Jones, S. Humphrey and K. Hughes, Altern. Ther., 2001, 7, 93-100.

3 S. Nobuko, K. Mutsuo, T. Harukuni, M. Teruo, E. Fumio, N. Hoyoku, N. Masahiro, S. Yohiro and H. L. Kuo, Bioorg. Med. Chem., 2005, 13, 1403-1408.

4 Chinese Pharmacopoeia Commission, The Pharmacopoeia of Chinese People's Republic, ed. Y. Li, The Chemical Industry Publishing House, Beijing, China, 2010, vol. 1, pp. 68-69.

5 Y. Nian, H. Zhu, W. R. Tang, Y. Luo, J. Du and M. H. Qiu, J. Nat. Prod., 2013, 76, 896-902.

6 Y. Nian, J. Yang, T. Y. Liu, Y. Luo, J. H. Zhang and M. H. Qiu, Sci. Rep., 2015, 5, 9026-9031.

7 J. X. Li and Z. Y. Yu, Curr. Med. Chem., 2006, 13, 2927-2951. 8 L. Wu, Z. L. Chen, Y. Su, Q. H. Wang and H. X. Kuang, Chin. J. Nat. Med., 2015, 13, 81-89.
9 Y. Su, L. Wu, G. Mu, Q. Wang, B. Yang, G. Cheng and H. X. Kuang, Bioorg. Med. Chem., 2017, 25, 4917-4923.

10 C. N. Lv, F. Yang, R. L. Qin, Z. Y. Qi, W. R. Zhou and J. C. Lu, Bioorg. Med. Chem. Lett., 2017, 27, 3305-3309.

11 N. M. Bao, Y. Nian, W. H. Wang, X. L. Liu, Z. T. Ding and M. H. Qiu, Phytochem. Lett., 2015, 12, 200-202.

12 W. H. Wang, Y. Nian, Y. J. He, L. S. Wan, N. M. Bao, G. L. Zhu, F. Wang and M. H. Qiu, Tetrahedron, 2015, 71, 8018-8025.

13 N. M. Bao, Y. Nian, G. L. Zhu, W. H. Wang, L. Zhou and M. H. Qiu, Fitoterapia, 2014, 99, 191-197.

14 Y. Nian, H. Y. Wang, L. Zhou, J. Su, Y. Li and M. H. Qiu, Planta Med., 2013, 79, 60-69.

15 Y. Nian, H. Y. Wang, J. Su, L. Zhou, G. Feng, Y. Li and M. H. Qiu, Tetrahedron, 2012, 68, 6521-6527.

16 Y. Nian, X. M. Zhang, Y. Li, Y. Y. Wang, J. C. Chen, L. Lu, L. Zhou and M. H. Qiu, Phytochemistry, 2011, 72, 1473-1481. 17 Y. Nian, Y. L. Zhang, J. C. Chen, L. Lu, C. Qing and M. H. Qiu, J. Nat. Prod., 2010, 73, 93-98.

18 Y. Nian, J. C. Chen, L. Lu, X. M. Zhang and M. H. Qiu, Helv. Chim. Acta, 2009, 92, 112-120.

19 L. Lu, J. C. Chen, Y. Li, C. Qing, Y. Y. Wang, Y. Nian and M. H. Qiu, Chem. Pharm. Bull., 2012, 60, 571-577.

20 H. Y. Wang, Y. Nian, C. Y. Ma, Y. B. Song, L. Zhou and M. H. Qiu, Chin. J. Chem., 2012, 30, 1265-1268.

21 D. S. Li, Y. Nian, Y. Sun and M. H. Qiu, Helv. Chim. Acta, 2011, 94, 632-638.

22 L. R. Sun, J. Yan, L. Zhou, Z. R. Li and M. H. Qiu, Molecules, 2011, 16, 5701-5708.

23 L. Lu, J. C. Chen, H. J. Song, Y. Li, Y. Nian and M. H. Qiu, Chem. Pharm. Bull., 2010, 58, 729-733.

24 L. Lu, J. C. Chen, H. J. Song, Y. Nian and M. H. Qiu, Molecules, 2009, 14, 1578-1584.

25 L. R. Sun, J. Yan, Y. Nian, L. Zhou, H. J. Zhang and M. H. Qiu, Molecules, 2008, 13, 1712-1721.

26 L. R. Sun, C. Qing, Y. L. Zhang, S. Y. Ji, Z. R. Li, S. J. Pei, M. H. Qiu, M. L. Gross and S. X. Qiu, Beilstein J. Org. Chem., 2007, 3, 1-6.

27 L. R. Sun, J. Yan, L. Lu, S. J. Pei, Z. R. Li, L. Zhou, X. M. Zhang and M. H. Qiu, Helv. Chim. Acta, 2007, 90, 1313-1318.

28 Z. Ali, S. L. Khan, R. S. Pawar, D. Ferreira and I. K. Khan, J. Nat. Prod., 2007, 70, 107-110.

29 C. Dan, Y. Zhou, Y. Deng, S. L. Peng, L. S. Ding, M. L. Gross and S. X. Qiu, Org. Lett., 2007, 9, 1813-1816.

30 J. C. Gao, F. Huang, J. C. Zhang, G. Y. Zhu, M. S. Yang and P. G. Xiao, J. Nat. Prod., 2006, 69, 1500-1502.

31 J. X. Li, J. Liu, C. C. He, Z. Y. Yu, Y. Du, S. Kadota and H. Seto, Maturitas, 2007, 58, 59-69.

32 N. Sakurai, J. H. Wu, Y. Sashida, Y. Mimaki, T. Nikaido, K. Koike, H. Itokawa and H. Lee, Bioorg. Med. Chem. Lett., 2004, 14, 1329-1332.

33 J. H. Lee, T. D. Cuong, S. J. Kwack, J. H. Seok, J. K. Lee, J. Y. Jeong, M. H. Woo, J. S. Choi, H. K. Lee and B. S. Min, Planta Med., 2012, 78, 1391-1394.

34 M. A. Findeis, F. Schroeder, T. D. McKee, D. Yager, P. C. Fraering, S. P. Creaser, W. F. Austin, J. Clardy, R. Wang, D. Selkoe and C. B. Eckman, ACS Chem. Neurosci., 2012, 3, 941-951. 
35 Y. Nian, H. Yan, X. N. Li, L. Zhou and M. H. Qiu, RSC Adv., 2017, 7, 38557-38564.

36 A. Enz, R. Amstutz, H. Boddeke, G. Gmelin and J. Malonowski, Prog. Brain Res., 1993, 98, 431-445.

37 E. K. Perry, Br. Med. Bull., 1986, 42, 63-69.

38 R. T. Bartus, L. D. Dean, B. Beer and A. S. Lippa, Science, 1982, 217, 408-417.

39 G. Benzi and A. Morreti, Eur. J. Pharmacol., 1998, 346, 1-13.

40 G. L. Ellman, K. D. Courtney, V. J. Andres and R. M. Featherstone, Biochem. Pharmacol., 1961, 7, 88-95.

41 L. A. Greene and A. S. Tischler, Proc. Natl. Acad. Sci. U. S. A., 1976, 73, 2424-2428.

42 M. J. Frisch, G. W. Trucks, H. B. Schlegel, G. E. Scuseria, M. A. Robb, J. R. Cheeseman, G. Scalmani, V. Barone, B. Mennucci, G. A. Petersson, H. Nakatsuji, M. Caricato, X. Li, H. P. Hratchian, A. F. Izmaylov, J. Bloino, G. Zheng, J. L. Sonnenberg, M. Hada, M. Ehara, K. Toyota, R. Fukuda, J. Hasegawa, M. Ishida, T. Nakajima, Y. Honda,
O. Kitao, H. Nakai, T. Vreven, J. A. Montgomery Jr, J. E. Peralta, F. Ogliaro, M. Bearpark, J. J. Heyd, E. Brothers, K. N. Kudin, V. N. Staroverov, R. Kobayashi, J. Normand, K. Raghavachari, A. Rendell, J. C. Burant, S. S. Iyengar, J. Tomasi, M. Cossi, N. Rega, J. M. Millam, M. Klene, J. E. Knox, J. B. Cross, V. Bakken, C. Adamo, J. Jaramillo, R. Gomperts, R. E. Stratmann, O. Yazyev, A. J. Austin, R. Cammi, C. Pomelli, J. W. Ochterski, R. L. Martin, K. Morokuma, V. G. Zakrzewski, G. A. Voth, P. Salvador, J. J. Dannenberg, S. Dapprich, A. D. Daniels, O. Farkas, J. B. Foresman, J. V. Ortiz, J. Cioslowski and D. J. Fox, Gaussian 09 Revision D.01, Gaussian Inc, Wallingford CT, USA, 2009.

43 T. Bruhn, A. Schaumlffl, A. Schaumlffl, Y. Hemberger, Y. Hemberger, G. Bringmann and G. Bringmann, SpecDis: quantifying the comparison of calculated and experimental electronic circular dichroism spectra, Chirality, 2013, 25, 243-249. 